\title{
PERANCANGAN BUSINESS ARCHITECTURE UNTUK FUNGSI AKADEMIK PADA INSTITUT XYZ MENGGUNAKAN FRAMEWORK TOGAF ADM STUDI KASUS SISTEM INFORMASI AKADEMIK (SIAKAD)
}

\author{
${ }^{1}$ Rahayu Manolita, ${ }^{2}$ Murahartawaty ${ }^{3}$ Ridha Hanafi \\ ${ }^{1,2,3}$ Program Studi Sistem Informasi, Fakultas Rekayasa Industri, Telkom University \\ ${ }^{1}$ rahayumanolita@gmail.com, ${ }^{2}$ murahartawaty@gmail.com, ${ }^{3}$ ridhanafi@gmail.com
}

\begin{abstract}
Abstrak-Institut XYZ merupakan institusi kepamongprajaan di lingkungan Departemen Dalam Negeri yang membantu menteri dalam melaksanakan program pendidikan vokasi, akademik, dan profesi di bidang kepamongprajaan. Dalam menunjang kegiatan organisasi untuk fungsional akademik digunakanlah Sistem Informasi Akademik (SIAKAD). Sistem informasi harus dirancang dengan baik sesuai dengan perencanaan sistem agar tidak terjadi kegagalan dan masalah dalam sistem yang disebabkan tidak adanya perencanaan sistem yang jelas, dan teknologi informasi yang dapat mendukung jalannya sistem informasi tersebut. Untuk menciptakan keselarasan strategi bisnis dan teknologi informasi organisasi dirancang sebuah enterprise architecture. Perancangan enterprise architecture untuk SIAKAD di institut XYZ menggunakan framework TOGAF ADM. TOGAF ADM bersifat fleksibel, interaktif dan detail serta cocok diimplementasikan untuk organisasi yang belum memiliki EA. Business Architecure merupakan fase ke tiga dalam TOGAF ADM yang berfungsi untuk mendefinisikan arsitektur baseline, menentukan model bisnis dan merancang arsitektur target yang nantinya akan menghasilkan sebuah blueprint arsitektur sebagai dasar pembangunan dan pengembangan sistem informasi akademik (SIAKAD) di institut XYZ.
\end{abstract}

Kata kunci: Enterprise Architecture, TOGAF ADM, Business Architecture, SIAKAD, Sistem Informasi Akademik.

\section{PENDAHULUAN}

Institut XYZ adalah lembaga pendidikan kepamongprajaan yang berada di lingkungan Kementerian Dalam Negeri, dibentuk dengan maksud untuk mempersiapkan kader pemerintahan dalam negeri yang siap tugas dan siap dikembangkan dalam rangka penyelenggaraan tugas pemerintahan dan pembangunan, baik di tingkat daerah maupun di tingkat pusat secara berdaya guna dan berhasil guna [1]. Institut XYZ sebagai center of knowledge merupakan pusat informasi dan riset dalam tata laksana pemerintahan, perencanaan wilayah, pusat studi E-government/ governance, peraturan dan perundangan terkait, Teknologi Tepat Guna (TTG) dan pendampingan, serta pemberdayaan masyarakat [1].

Perancangan sistem informasi yang baik harus dilihat dari berbagai sudut pandang pengembangan sistem, dimulai dari mendefinisikan arsitektur bisnis dalam organisasi, mendefinisikan arsitektur data yang akan digunakan, mendefinisikan arsitektur aplikasi yang akan dibangun, serta mendefinisikan arsitektur teknologi yang mendukung jalannya sistem informasi tersebut [2].

Sistem Informasi Akademik adalah sistem yang dirancang khusus untuk memenuhi kebutuhan sebuah perguruan tinggi yang telah terkomputerisasi untuk melakukan kegiatan akademik secara terstruktur sehingga segala proses yang seharusnya memerlukan waktu yang banyak, tetapi dapat teratasi dengan waktu yang cepat [3].

Sebagai sebuah institusi pemerintahan, XYZ telah menggunakan sistem informasi sebagai penunjang kegiatan organisasi, yaitu Sistem Informasi Akademik (SIAKAD) yang digunakan sebagai sarana penunjang dalam meningkatkan pelayanan akademik. Dalam implementasinya, SIAKAD dikelola oleh bagian akademik di setiap fakultas dan digunakan oleh bagian akademik, mahasiswa, praja, dan dosen. Diperlukan adanya pengelolaan sistem informasi dan teknologi informasi untuk mendukung tata kelola TI pada institut XYZ dengan menyediakan dan memanfaatkan ICT dalam manajemen perguruan tinggi kepamongprajaan. Pembangunan dan pengembangan sistem informasi harus selaras dengan strategi bisnis dan TI suatu organisasi untuk mencapai tujuannya.

Dengan adanya Enterprise Architecture (EA) maka akan memberikan penjelasan dan dokumentasi saat ini dan yang diinginkan antara bisnis dan teknologi informasi, di dalamnya akan menggambarkan arsitektur baseline dan arsitektur target sehingga akan tercipta keselarasan antara strategi bisnis dan TI.

TOGAF ADM diadopsi untuk mengimplementasikan EA di institut XYZ. Mengenai beberapa EA framework yang baik, diketahui bahwa TOGAF ADM memenuhi semua kriteria yang telah ditentukan dalam menilai EA framework dan framework yang cocok diimplementasikan untuk organisasi yang belum memiliki EA adalah TOGAF ADM [4]. Selain itu, TOGAF ADM merupakan framework yang fleksibel, detail dan iteratif.

Business architecture merupakan fase ketiga yang ada di framework TOGAF ADM. Arsitektur ini mendefinisikan baseline arsitektur bisnis, menentukan model bisnis atau 
aktivitas bisnis yang diinginkan berdasarkan skenario bisnis [5]. Pentingnya Business Architecture dalam suatu organisasi yaitu untuk memetakan kebutuhan bisnis dan TI di seluruh lingkup organisasi.

\section{METODOLOGI PENELITIAN}

\section{A. Model Konseptual}

Berdasarkan model konseptual pada Gambar 1 dapat dilihat bahwa model konseptual ini memiliki beberapa elemen utama yaitu input dan output. Kedua elemen tersebut merupakan gambaran umum dari penelitian mengenai perancangan Business Architectureuntuk SIAKAD yang ada di institut XYZ.

Elemen pertama pada model konseptual yaitu input. Input-an dari penelitian ini yaitu rencana strategis institut XYZ, permendagri No. 39 Tahun 2009, dokumen pengembangan dan perencanaan Sistem Informasi Akademik baseline, dan rencana strategi TI institut XYZ serta output dari Architecutre Vision yang berupa dokumen yang berisikan pendefinisian ruang lingkup, identifikasi stakeholder, dan visi arsitektur, lalu kompenen data, komponen aplikasi, dan komponen teknologi digunakan untuk membuat Data Architecture, Application Architecture, dan Technology Architecture.

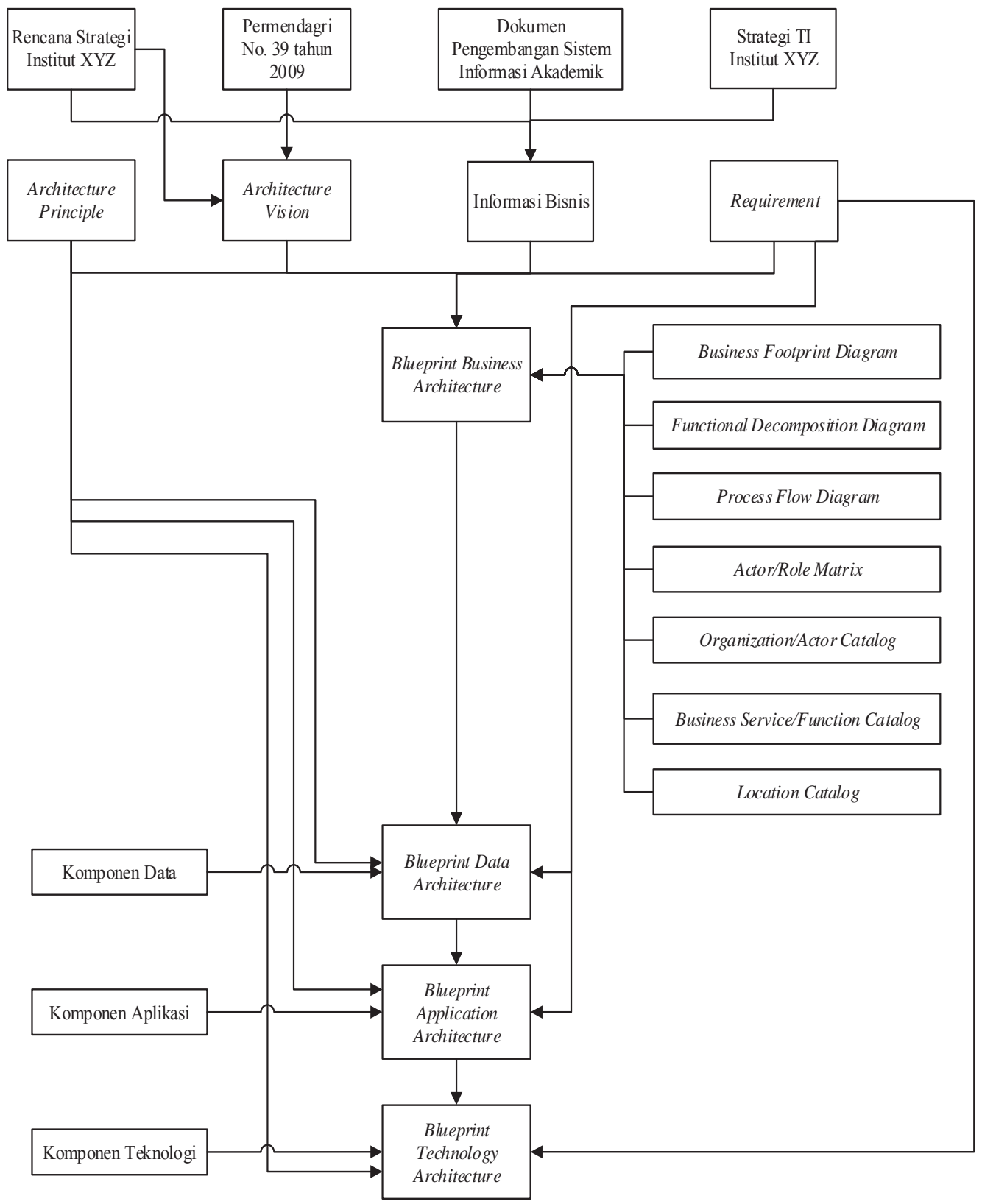

Gambar 1 Model Konseptual 
Elemen kedua yaitu output. Output yang dihasilkan berupa blueprint Business Architecture terdiri dari Business Footprint Diagram, Functional Decomposition Diagram, Process Flow Diagram, Actor/Role Matrics, Organization/Actor Catalog, Business Services/Function Catalog, Location Catalog, serta blueprint Data Architecture, blueprint Application Architecture, dan blueprint Technology Architecture, yang nantinya dapat menjadi pedoman atau guideline dalam membangun SIAKAD pada institut XYZ.

\section{B. Sistematika Penelitian}

Sistematika penelitian ini terdiri dari lima fase, yaitu fase perencanaan, fase analisis, fase desain, fase pelaporan, dan fase kesimpulan dan saran. Berikut ini merupakan penjelasan dari setiap fase pada sistematika penelitian ini

\section{Fase Perencanaan}

Fase perencanaan merupakan fase awal dalam penelitian yang mendefinisikan seluruh persiapan dan perencanaan yang dilakukan dalam melakukan penelitian.

Penelitian ini diawali dengan penetapan rumusan masalah, kemudian dilanjutkan dengan penetapan tujuan penelitian dan ruang lingkup masalah, selanjutnya dilakukan tahapan studi pustaka dan studi lapangan. Dalam penelitian kali ini framework yang digunakan adalah TOGAF ADM pada fase Business Architecture untuk membuat sebuah rancangan blueprintBusiness Architecture pada institut XYZ.

2. Fase Analisis

Fase analisis dilakukan pemetaan Architecture Vision, selanjutnya dilakukan pembuatan pertanyaan wawancara dan dilakukan observasi, lalu dilakukan proses identifikasi terhadap tujuan bisnis yang terdapat dalam Rencana Strategis organisasi, identifikasi bisnis skenario ataupun proses bisnis yang terdapat pada dokumen baseline pengembangan SIAKAD, dan visi institut XYZ. Selanjutnya dilakukan identifikasi terhadap data Business Architecture yang telah dimiliki oleh institut XYZ untuk dijadikan acuan untuk pengembangan Business Architecture target pada institut XYZ.

\section{Fase Desain}

Fase desain diawali dengan mendefinisikan Business Architecture baseline yang menggambarkan kondisi baseline dari institut XYZ lalu merancang Business Architecture yang diinginkan kedepannya. Setelah itu dilakukan analisis gap untuk mengetahui gap yang ada pada arsitektur baseline dengan arsitektur target. Setelah mengetahui gap yang ada, maka dibuatlah roadmap pengembangan arsitektur, jika tidak divalidasi dan diverifikasi maka dilakukan peninjauan ulang terhadap pendefinisian Business Architecture baseline, namunjika sesuai maka dilanjutkan dengan fase berikutnya.

4. Fase Pelaporan

Fase pelaporan yaitu setelah fase perancangan telah memenuhi kebutuhan pengembangan SIAKAD, kemudian dokumen yang dihasilkan adalah blueprint Business Architecture sebagai acuan untuk pengembangan SIAKAD pada institut XYZ.

5. Fase Kesimpulan dan Saran

Fase terakhir pada penelitian ini adalah fasekesimpulan dan saran. Fase ini terdiri dari dua bagian yaitu bagian kesimpulan dan bagian saran. Pada bagian kesimpulan berisikan kesimpulan dari hasil guideline, blueprint Business Architecture yang telah dilakukan pada penelitian ini. Pada bagian saran berisikan saran-saran yang diberikan untuk membantu organisasi dalam melakukan penilaian dalam kinerjanya.

\section{HASIL DAN PEMBAHASAN}

Ruang lingkup penelitian ini tidak mengambil seluruh fase pada TOGAF ADM, hanya fase Preliminary, fase Architecture Vision, dan fase Business Architecture yang akan dibahas pada penelitian ini.

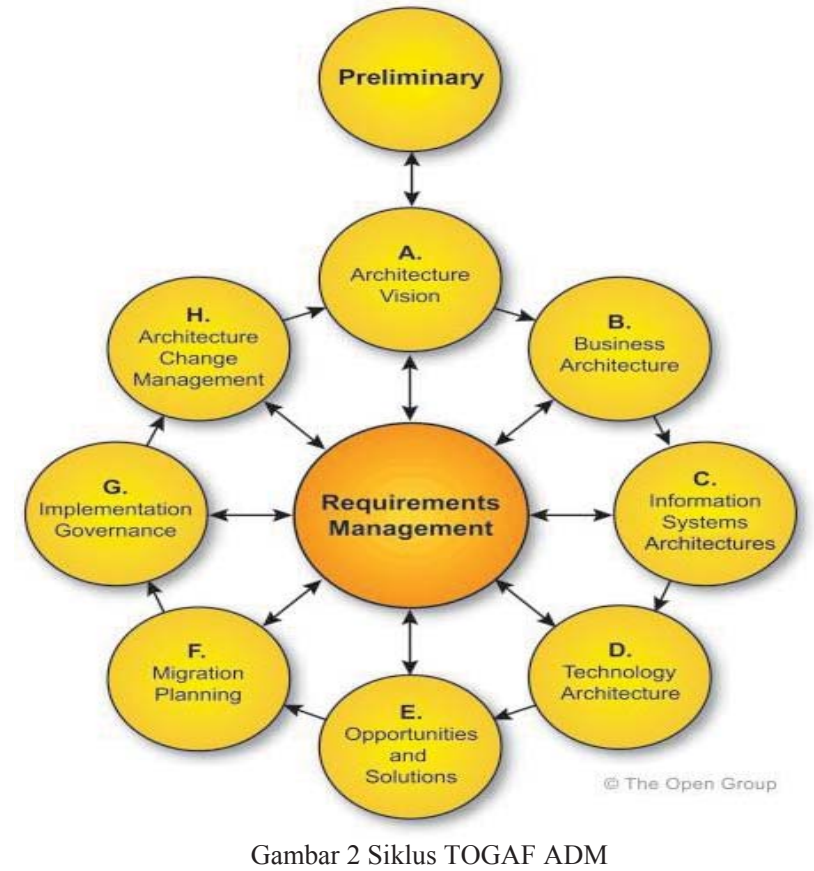

A. Fase Preliminary

Tahap ini mendeskripsikan aktivitas inisiasi dan aktivitas persiapan dalam rangka memenuhi kriteria arah bisnis untuk Enterprise Architecture, termasuk definisi dari prinsip - prinsip arsitektur. Prinsip arsitektur menjadi dasar dalam pengambilan keputusan terkait IT. Oleh karena itu, setiap prinsip yang dibuat mengacu pada keinginan untuk membangun sebuah perancangan arsitektur teknologi informasi yang sesuai dengan institut dan dapat membantu dalam mencapai visi dan misi. Prinsip-prinsip bisnis, yaitu sebagai berikut.

\section{Business Continuity}

Aktivitas institut tetap diselenggarakan meskipun terjadi gangguan sistem. Oleh karena itu, kita harus membuat perencanaan yang baik untuk menangani gangguan pada sistem, mempertimbangkan keandalan sistem, seluruh desain dan penggunaannya.

\section{Common Use Applications}

Pengembangan aplikasi yang standar dapat digunakan di seluruh unit lebih baik daripada pengembangan aplikasi yang sama untuk beberapa organisasi sehingga dapat mencegah terjadinya duplikasi aplikasi. 


\section{Compliance with Law}

Proses manajemen informasi pada institut XYZ harus mematuhi semua undang-undang, kebijakan, dan peraturan.

4. Information Management is Everybody's Business

Semua unit berpartisipasi dalam keputusan manajemen informasi yang dibutuhkan untuk mencapai tujuan bisnis.

5. IT Responsibility

Organisasi/aktor TI bertanggung jawab untuk memiliki dan melaksanakan proses TI dan infrastruktur yang memungkinkan untuk memenuhi kebutuhan yang telah ditetapkan pengguna dari fungsional, tingkat layanan, biaya, dan waktu pengembangan.

\section{Maximize Benefit to the Enterprise}

Secara keseluruhan, keputusan manajemen informasi dibuat untuk memberikan manfaat maksimal kepada institut ini. Teknologi informasi diharapkan dapat memberikan manfaat yang signifikan.

\section{Primacy of Principle}

Prinsip-prinsip manajemen informasi berlaku untuk semua unit dalam perusahaan. Seluruh organisasi harus mematuhi prinsip - prinsip untuk menghasilkan informasi yan berkualitas dan konsisten yang dapat membantu para stakeholder.

\section{Protection of Intellectual Property}

Perlindungan terhadap aset intelektual organisasi harus tercermin didalam arsitektur TI, pelaksanaan dan proses tata kelola sehingga seluruh aset yang bersifat confidential dapat terlindungi.

\section{Service Orientation}

Arsitektur atau sistem yang dibuat didasarkan pada layanan yang mencerminkankegiatan bisnis yang terdiri dari proses bisnis institute XYZ.

\section{B. Fase Architecture Vision}

Pada saat melakukan analisis pada fase ini dilakukan identifikasi requirement, requirement ini merupakan requirement high level berupa visi dari institut XYZ.

Hasil identifikasi requirement untuk fase architecture vision berdasarkan visi dan misi yang ada di institut XYZ, yaitu:

1. mengembangkan kepribadian dan karakter civitas akademika;

2. pemenuhan standar mutu pendidikan tinggi berbasi teknologi informasi dan komunikasi;

3. meningkatkan penggunaan teknologi informasi dan komunikasi di kalangan civitas akademika.

\section{Fase Business Architecture}

Arsitektur bisnis menggambarkan kondisi awal arsitektur bisnis, menentukan model bisnis atau aktivitas bisnis yang diinginkan berdasarkan skenario bisnis. Arsitektur ini akan menjadi landasan untuk perancangan fase data arsitektur, aplikasi aritektur dan teknologi arsitektur.

Pada fase ini juga dilakukan analisis terhadap fungsi bisnis yang ada pada institut XYZ, kemudian dibandingkan dengan requirement yang telah diidentifikasi sebelumnya. Apabila terdapat fungsi bisnis yang belum memenuhi requirement yang diinginkan, maka akan dilakukan perbaikan atau penambahan fungsi bisnis untuk Business Architecture Target sehingga nantinya akan sesuai dengan kebutuhan institut XYZ.

Berdasarkan penelitian yang telah dilakukan maka dihasilkan beberapa artifakdari fase ini, diantaranya Hirarki Fungsi Bisnis, Business Footprint Diagram, Functional Decomposition Diagram, Process Flow Diagram, Actor/Role Matrics, Organization/Actor Catalog, Business Services/Function Catalog, Location Catalog.

Hirarki fungsi bisnis menjelaskan fungsi bisnis institut XYZ secara keseluruhan Dari hasil identifikasi, terdapat 255 fungsi dan subfungsi baseline, dan terdapat 275 fungsi dan sub fungsi target pada institut XYZ, artinya terdapat dua puluh fungsi bisnis yang ditambahkan khususnya pada fungsional akademik agar seluruh requirement dapat dipenuhi.

Business footprint diagram mendeskripsikan hubungan antara driver, business goals, objectives, business functions \& services, serta memetakannya ke dalam komponen teknis. Terdapat dua driver pada target yang dirancang untuk institut XYZ, yaitu kemajuan teknologi informasi di dunia pendidikan dan kebutuhan akan kader pemerintahan yang berkualitas. Dari driver ini maka juga dipetakan dua goals yang harus dicapai oleh institut XYZ, yaitu mengembangkan sarana dan infrastruktur dalam bidang akademik sesuai standar mutu pendidikan tinggi, dan meningkatkan mutu dan kinerja penyelenggaraan pendidikan yang mengarah pada pemenuhan standar mutu pendidikan nasional berbasis teknologi informasi dan komunikasi. Maka untuk mencapai dua goals tersebut dipetakan sejumlah objectives seperti meningkatkan pengelolaan layanan TI, meningkatkan pelayanan akademik, mengoptimalkan pelaksanaan dan pengembangan pendidikan, meningkatkan pengelolaan dan pembinaan alumni, pengendalian dan pengontrolan kegiatan keprajaan, mengoptimalkan pengabdian kepada masyarakat, mengoptimalkan proses seleksi dan penerimaan calon praja, melaksanakan proses pengajaran, pelatihan dan pengasuhan. Untuk mencapai objectives tersebut maka diperlukan fungsi bisnis pada institut XYZ, fungsi bisnis yang telah dirancang, yaitu seleksi dan penerimaan calon praja, pengasuhan praja, pengelolaan dan pembinaan alumni, pelaksanaan dan pengembangan pendidikan dan pelatihan, kegiatan keprajaan, pengabdian kepada masyarakat, pengelolaan layanan teknologi informasi, perencanaan dan perumusan strategi pengabdian kepada masyarakat, pengasuhan praja. Secara keseluruhannya, business footprint diargam target dapat dilihat pada Gambar 3 .

Functional decomposition diagram menunjukkan kapabilitas dan fungsi dari setiap bagian atau unit perusahaan yang relevan dalam aktivitas bisnis. Diagram ini menunjukkan perspektif fungsional dari setiap bagian atau divisi perusahaan. Pada institut XYZ ini terdapat empat belas fungsional akademik baseline dan dirancang lima belas fungsional akademik target, penambahan satu fungsional akademik pada target tersebut merupakan pemisahan fungsi Pengelolaan Laboratorium. Gambar 2 menunjukkan functional decomposition diagram target di institut $\mathrm{XYZ}$, kolom yang berwarna oranye merupakan fungsional akademik. 
Process flow diagram digunakan untuk menggambarkan alur fungsi bisnis akademik serta aktor atau unit-unit yang ikut terlibat dalam menjalankan aktivitas yang terdapat pada fungsi bisnis akademik Dengan menggambarkan alur proses ini, kita dapat melihat bagaimana alur proses bisnis akademik yang berjalan dalam di institut XYZ dan data-data yang dapat menjadi masukan dan keluaran dari suatu proses yang menjadi masukan untuk proses selanjutnya. Terdapat empat belas alur proses target yang telah dirancang, diantaranya pengelolaan input dan perbaikan nilai praja, pengelolaan e-learning, pengelolaan class conference, pengelolaan jadwal pelatihan praja, pelaporan presensi praja menggunakan sistem, pengelolaan nilai dan hasil pelatihan praja, pengelolaan silabus online, seleksi penerimaan dan ujian testing calon praja menggunakan sistem.

Actor/Role Matrics berfungsi untuk menunjukkan peran dan tanggung jawab aktor atau unit-unit organisasi terhadap fungsional akademik perusahaan. Dengan matriks ini akan terlihat siapa yang memiliki tugas dan bertanggung jawab terhadap suatu proses yang terdapat dalam perusahaan. Matriks ini dinotasikan dengan RACI. RACI terdiri dari empat peran yaitu Responsible, Accountable, Consulted, dan Informed. Contoh Actor/Role Matrics Target dapat dilihat pada Tabel 1.

Organization/Actor Catalog merupakan deskripsi unitunit yang terlibat dalam menjalankan setiap fungsi dan proses bisnis pada institut XYZ. Pada institut XYZ ini terdapat 28 unit yang terlibat dalam menjalankan fungsi bisnis, artinya tidak terdapat penambahan atau pengurangan unit organisasi dalam menjalankan bisnis, unit-unit tersebut diantaranya adalah

\section{SUPPORT ACTIVITIES}

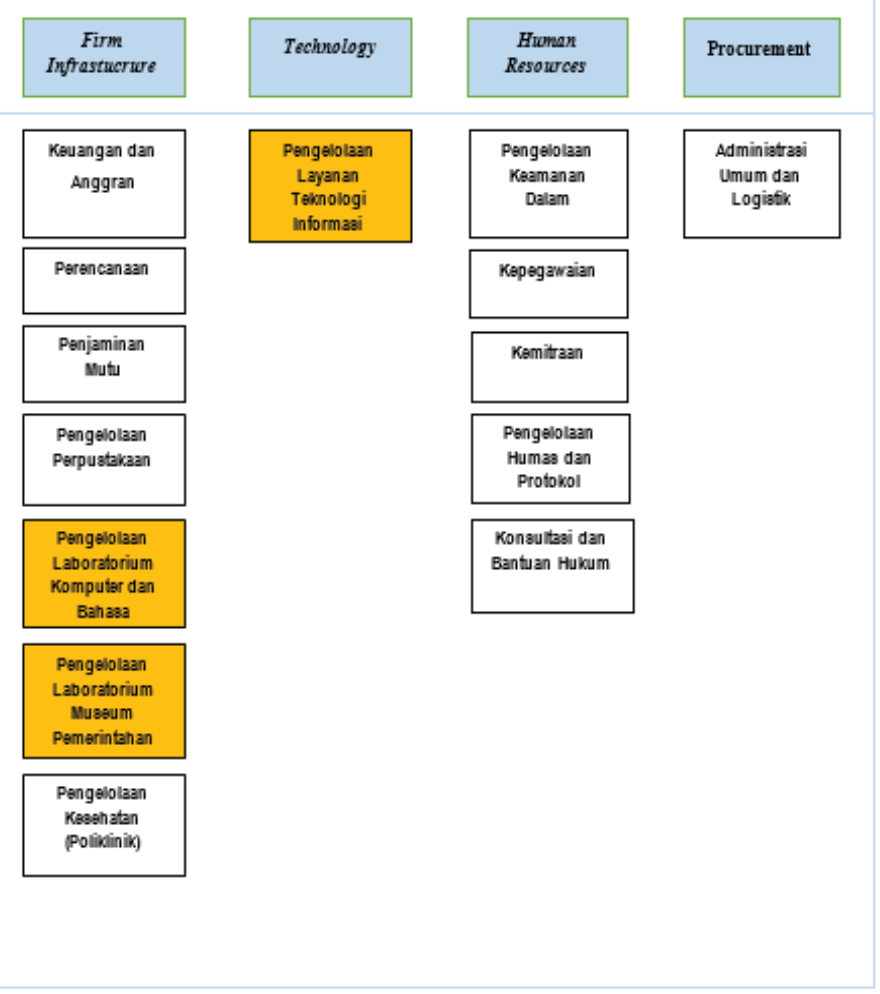

rektorat, pascasarjana, fakultas, lembaga penelitian, lembaga pengabdian kepada masyarakat, bagian TU fakultas manajemen pemerintahan, bagian TU fakultas politik pemerintahan, bagian akademik, bagian perencanaan, bagian pelatihan, bagian kerjasama, bagian kepegawaian, bagian keuangan, unit laboratorium komputer dan bahasa, unit laboratorium museum pemerintahan, unit pelayanan teknologi informasi dan komunikasi.

Business Services/Function Catalog merupakan penjelasan dari layanan-layanan akademik yang terdapat pada institute XYZ. Sesuai dengan adanya penambahan fungsi bisnis, maka terdapat beberapa penambahan layanan-layanan terkait akademik, seperti pengelolaan rekruitmen praja menggunakan sistem, pengelolaan perwalian dengan dosen, pengelolaan class conference, pengelolaan e-learning, pelaporan presensi praja menggunakan sistem, pengelolaan pengajuan skripsi praja menggunakan sistem, penetapan syarat lulus dan wisuda praja, pengkoordinasian jadwal praktikum praja.

Location Catalog menggambarkan daftar lokasi-lokasi dalam melaksanakan fungsional akademik institut XYZ. Terdapat delapan lokasi dalam menjalankan fungsional akademik institut XYZ, yaitu Kampus XYZ Jatinangor, Kampus XYZ Cilandak S1, Kampus XYZ Nusa Tenggara Barat, Kampus XYZ Sulawesi Selatan, Kampus XYZ Sulawesi Utara, Kampus XYZ Sumatera Barat, Kampus XYZ Papua, Kampus XYZ Riau, dan Kampus XYZ Kalbar. Secara keseluruhan, Kampus XYZ Jatinangor merupakan pusat pengendalian seluruh kegiatan pendidikan.

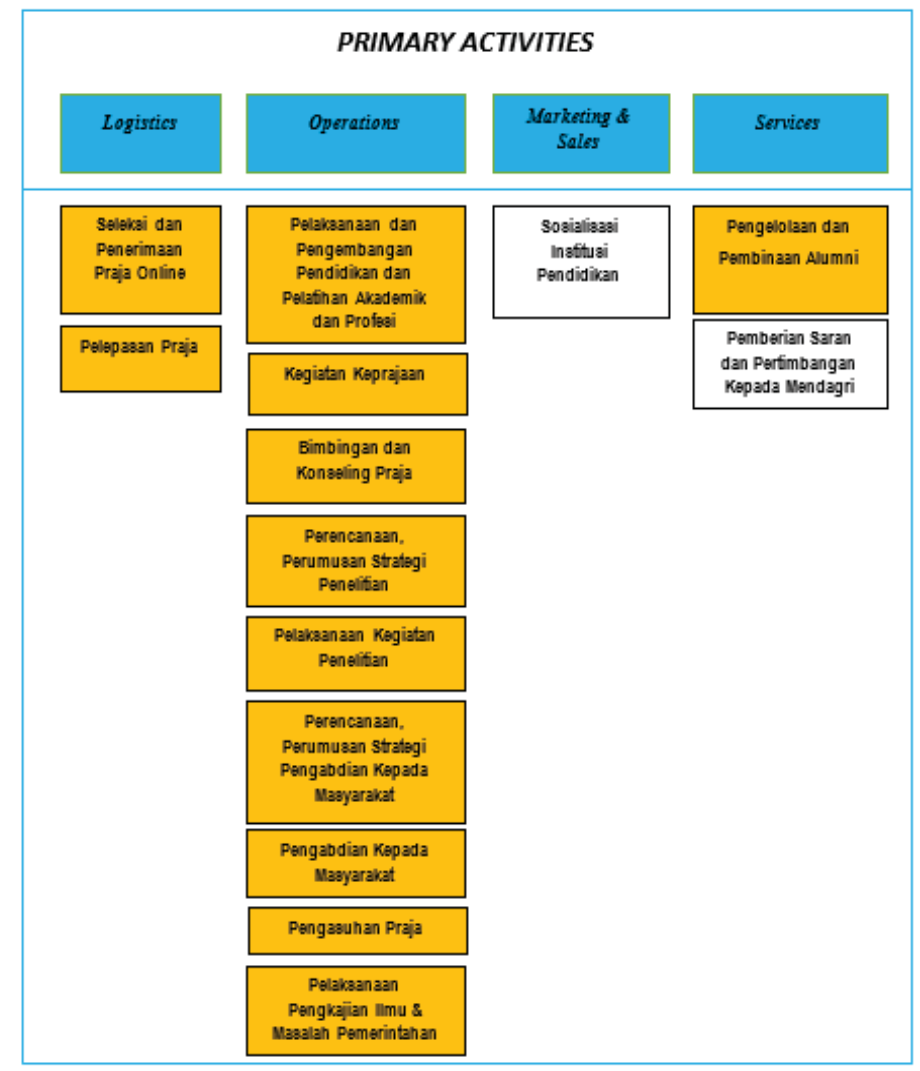




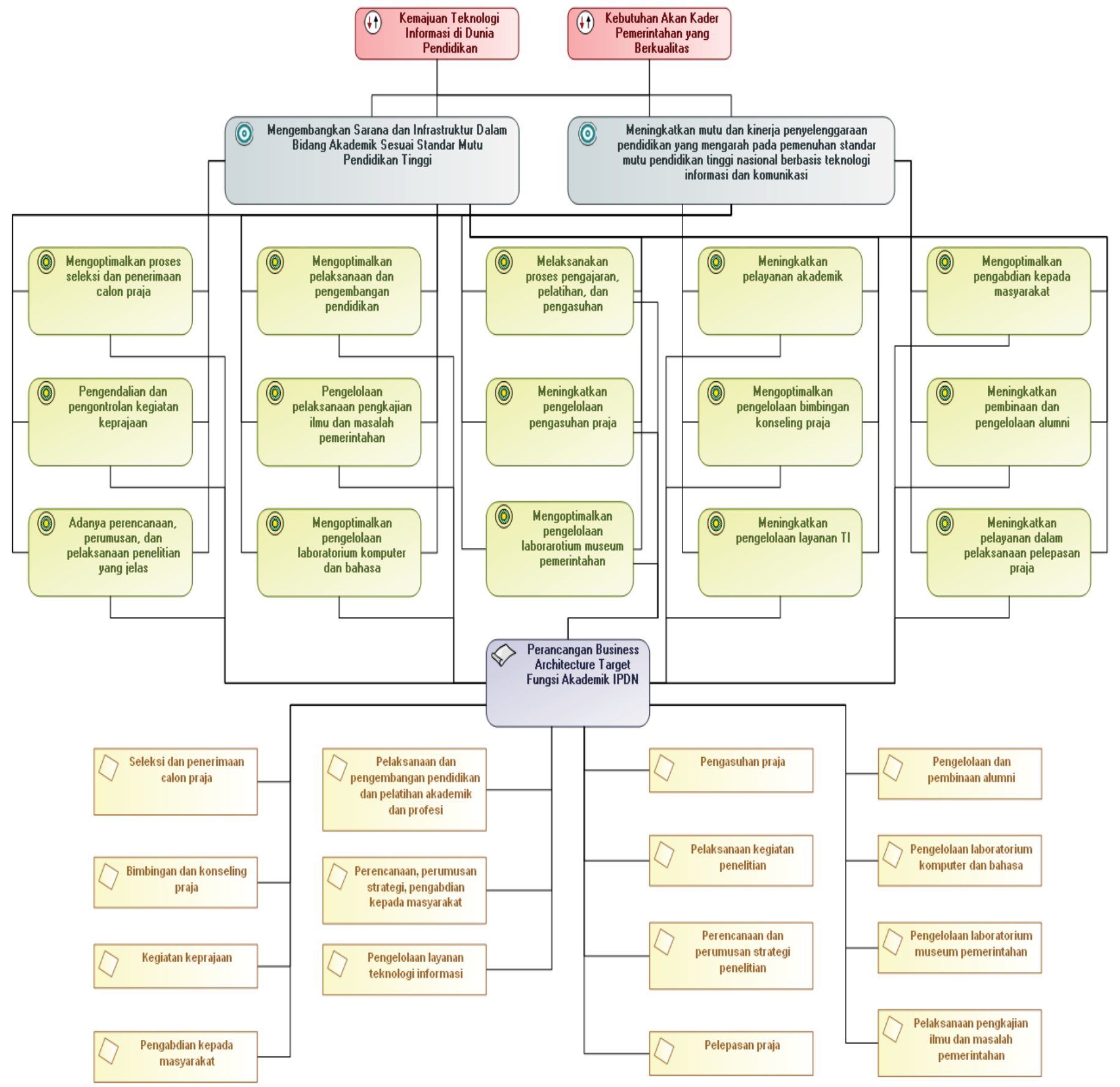

Gambar 3 Business Footprint Diagram Target

Perancangan Business Architecture untuk Fungsi Akademik pada Institut XYZ 
TABEL I

CONTOH ACTOR/ROLE MATRICS TARGET

\begin{tabular}{|c|c|c|c|c|c|c|c|c|c|c|c|c|c|c|c|c|c|}
\hline Fungsi Organisasi & $\frac{\hbar}{\frac{0}{0}}$ & 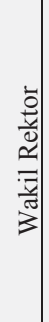 & 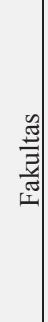 & 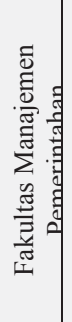 & 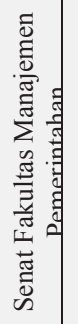 & 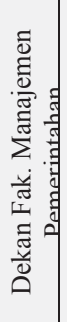 & 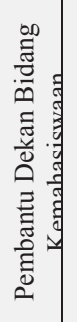 & 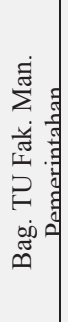 & 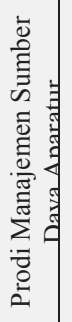 & 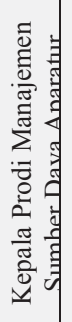 & 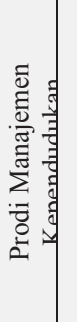 & 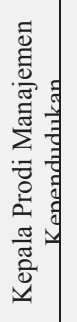 & 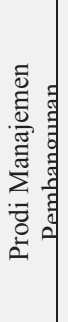 & 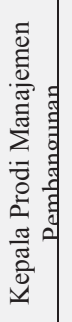 & 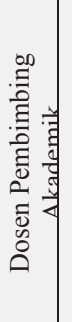 & 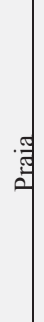 & $\begin{array}{l}\text { ठี } \\
\text { ஜ } \\
\text { คి }\end{array}$ \\
\hline $\begin{array}{l}\text { Penyelenggaraan pendaftaran calon praja dengan } \\
\text { menggunakan sistem }\end{array}$ & $\begin{array}{l}\mathrm{C} \\
\mathrm{I}\end{array}$ & C & & & & & & & & & & & & & & $\mathrm{R}$ & \\
\hline $\begin{array}{l}\text { Penyelenggaraan ujian dan testing calon praja } \\
\text { dengan menggunakan sistem }\end{array}$ & $\begin{array}{l}\mathrm{C} \\
\mathrm{I}\end{array}$ & C & & & & & & & & & & & & & & $\mathrm{R}$ & \\
\hline $\begin{array}{l}\text { Penyiapan bahan pengembangan kurikulum } \\
\text { pendidikan (pelatihan, pengajaran dan pengasuhan) } \\
\text { IPDN }\end{array}$ & $\begin{array}{l}\mathrm{C} \\
\mathrm{I}\end{array}$ & $\begin{array}{l}\mathrm{C} \\
\mathrm{I}\end{array}$ & C & $\begin{array}{c}\mathrm{C}, \\
\mathrm{I}\end{array}$ & & & & & & $\begin{array}{c}\text { C, } \\
\text { I }\end{array}$ & & $\begin{array}{c}\mathrm{C}, \\
\mathrm{I}\end{array}$ & & C, & & & $\mathrm{R}$ \\
\hline Pengelolaan jadwal kuliah praja per semester & & & C & & & & & & & & & & & & & & \\
\hline Pengelolaan input dan perbaikan nilai praja & & & $\mathrm{R}$ & $\mathrm{R}$ & & I & & & $\mathrm{R}$ & $\mathrm{R}$ & $\mathrm{R}$ & $\mathrm{R}$ & $\mathrm{R}$ & $\mathrm{R}$ & & $\mathrm{R}$ & $\mathrm{R}$ \\
\hline
\end{tabular}

IV. KESIMPULAN

Perancangan enterprise architecture pada penelitian ini menggunakan framework TOGAF ADM, dengan menghasilkan beberapa artefak pada fase preliminary, architecture vision dan business architecture. Berdasarkan hasil analisis yang telah dilakukan, terdapat beberapa fungsi bisnis akademik baseline yang belum memenuhi requirement organisasi sehingga diperlukan perbaikan dan penambahan fungsi bisnis yang menjadi fungsi bisnis akademik target. Perancangan arsitektur pada penelitian ini menghasilkan blueprint yaitu blueprint Business Architecture.

\section{DAFTAR PUSTAKA}

[1] Rektor IPDN. Peraturan Rektor IPDN Nomor 13 Tahun 2010 Tentang Rencana Strategis Institut Pemerintahan Dalam Negeri Republik Indonesia, 2010.

[2] Roni Yunis, K. S. Perancangan Model Enterprise Architecture dengan TOGAF Architecture Development Method, 2009 SNATI, Yogyakarta, Indonesia, Juni 2009, pp. E25.

[3] Kasenda, M. G. Perancangan dan Implementasi Sistem Informasi Akademik Berbasis EPSBED pada Universitas Negeri Manado. 6.

[4] Setiawan, E. B. Pemilihan EA Framework, 2009 SNATI, Yogyakarta, Indonesia, Juni 2009, pp. B115.

[5] Tambunan, A. F. Perancangan Business Architecture dan Data Architecture untuk Implementasi System Application Product (SAP) menggunakan The Open Group Architecture Framework Architecture Development Method (TOGAF ADM) pada PT Kereta Api Indonesa (Persero).TA, Program Studi Sistem Informasi, Telkom University, 2014. 